\title{
Neutrophil elastase cleaves the murine hemidesmosomal protein BP180/type XVII collagen and generates degradation products that modulate experimental Bullous Pemphigoid
}

\author{
Lan Lin ${ }^{\mathrm{a}, \mathrm{b}}$, Tomoko Betsuyaku ${ }^{\mathrm{c}}$, Lisa Heimbach ${ }^{\mathrm{b}, \mathrm{d}}$, Ning Li ${ }^{\mathrm{b}}$, David Rubenstein ${ }^{\mathrm{b}, \mathrm{e}}$, Steven D. \\ Shapiro ${ }^{f}$, Lijia An ${ }^{a}$, George J. Giudice ${ }^{g}$, Luis A. Diaz ${ }^{b}$, Robert M. Senior ${ }^{h}$, and Zhi Liub,d, \\ aDalian University of Technology, Dalian, Liaoning, P.R.C. \\ bDepartment of Dermatology, University of North Carolina, Chapel Hill, NC, U.S.A. \\ 'First Department of Medicine, Hokkaido University School of Medicine, Sapporo, Japan \\ ${ }^{\mathrm{d} D e p a r t m e n t}$ of Microbiology and Immunology, University of North Carolina, Chapel Hill, NC, \\ U.S.A. \\ eDepartment of Pharmacology, University of North Carolina, Chapel Hill, NC, U.S.A. \\ fPulmonary, Allergy, and Critical Care Medicine, University of Pittsburgh, Pittsburgh, PA 15213, \\ U.S.A. \\ 9Department of Dermatology, University of lowa, lowa City, IA 52246, U.S.A. \\ hPulmonary and Critical Care Medicine, Washington University, St. Louis, MO, U.S.A.
}

\begin{abstract}
Bullous pemphigoid (BP) is an autoimmune subepidermal blistering disease associated with autoantibodies against the hemidesmosomal proteins BP180 and BP230. In the IgG passive transfer model of BP, blister formation is triggered by anti-BP180 IgG and depends on complement activation, mast cell degranulation, and neutrophil recruitment. Mice lacking neutrophil elastase (NE) do not develop experimental BP. Here, we demonstrated that NE degrades recombinant mouse BP180 within the immunodominant extracellular domain at amino acid positions 506 and 561, generating peptide p561 and peptide p506. Peptide p561 is chemotactic for neutrophils both in vitro and in vivo. Local injection of NE into B6 mice recruits neutrophils to the skin, and neutrophil infiltration is completely blocked by co-injection with the NE inhibitor $\alpha 1$-proteinase inhibitor. More importantly, NE directly cleaves BP180 in mouse and human skin, as well as the native human BP180 trimer molecule. These results demonstrate that (i) NE directly damages the extracellular matrix and (ii) NE degradation of mouse BP180 generates neutrophil chemotactic peptides that amplify disease severity at the early stage of the disease.
\end{abstract}

\footnotetext{
(C) 2011 Elsevier B.V. All rights reserved

*Address correspondence to: Dr. Zhi Liu, 422 Mary Ellen Jones Building, Department of Dermatology, University of North Carolina, Chapel Hill, NC 27599; Tel: 919-966-0788; Fax: 919-966-3898; zhiliu@ med.unc.edu.

Publisher's Disclaimer: This is a PDF file of an unedited manuscript that has been accepted for publication. As a service to our customers we are providing this early version of the manuscript. The manuscript will undergo copyediting, typesetting, and review of the resulting proof before it is published in its final citable form. Please note that during the production process errors may be discovered which could affect the content, and all legal disclaimers that apply to the journal pertain.

${ }^{1}$ Abbreviations used in this paper: BMZ, basement membrane zone; BP, bullous pemphigoid; mBP180, murine BP180 antigen; MPO, myeloperoxidase; NE, neutrophil elastase.
} 


\section{Keywords}

bullous pemphigoid; chemotaxis; basement membrane; neutrophil elastase; BP180; autoimmune mouse model

\section{Introduction}

Bullous pemphigoid (BP) ${ }^{1}$ is an autoimmune skin blistering disease that primarily afflicts the elderly (Lever, 1953). BP is characterized by the development of tense, fluid-filled blisters on the body, separation of the epidermis from the dermis, an intense inflammatory infiltrate, and the destruction of components of the hemidesmosome and extracellular matrix (Jordon et al., 1967; Stanley, 1999). Patients exhibit circulating and tissue-bound autoantibodies directed against the hemidesmosomal antigens BP230 and BP180 (Stanley, 1999; Stanley et al., 1981). BP180, also known as BPAG2 or type XVII collagen, is the primary target of the pathogenic autoantibodies in BP patients (Bedane et al., 1997; Diaz et al., 1990; Giudice et al., 1992; Giudice et al., 1993; Hopkinson et al., 1992; Labib et al., 1986; Mutasim et al., 1985; Nishizawa et al., 1993). A type II transmembrane glycoprotein that exists as a homo-trimer in the skin (Hirako et al., 1996; Van den Bergh et al., 2006), BP180's amino-terminal portion localizes to the hemidesmosomal plaque and the carboxylterminal region extends into the extracellular region of the basement membrane zone (BMZ) (Giudice et al., 1992; Hopkinson et al., 1992; Ishiko et al., 1993). The extracellular portion of BP180 consists of 15 collagen domains interrupted by 16 non-collagen (NC) sequences (Giudice et al., 1992). The membrane-proximal non-collagen linker domain (termed NC16A) harbors multiple epitopes recognized by BP autoantibodies (Giudice et al., 1993; Zillikens et al., 1997). The human BP180 shares high overall homology with the murine BP180 (mBP180); but mBP180 contains 13 collagen domains and 14 non-collagen domains (Li et al., 1993). Moreover, the NC16A domain is very poorly conserved in the murine protein (termed NC14A), resulting in a lack of immune-reactivity across these two species (Liu et al., 1993).

We have previously described a mouse model of BP in which disease is induced by the passive transfer of antibodies directed against mouse BP180 (Liu et al., 1993). Neonatal $\mathrm{BALB} / \mathrm{c}$ mice injected with these antibodies develop a blistering skin disease that exhibits the key immunopathologic features of BP. Using this animal model, we have shown that the antibody-induced lesion formation is dependent on complement activation, mast cell degranulation, and neutrophil infiltration of the upper dermis (Chen et al., 2001; Liu et al., 1995; Liu et al., 1997).

Upon activation, infiltrating neutrophils secrete proteolytic enzymes known to degrade the extracellular matrix, including neutrophil elastase (NE), matrix metallopeptidase-9 (MMP-9), cathepsin G, and collagenase (Janoff, 1985; Senior and Campbell, 1983; Weiss, 1989). These proteinases, along with others such as plasmin and plasminogen activators, have been detected in BP blister fluid and within lesional/perilesional skin sites on BP patients (Gissler et al., 1992; Grando et al., 1989a; Grando et al., 1989b; Kramer and Reinartz, 1993; Oikarinen et al., 1983; Stahle-Backdahl et al., 1994; Welgus et al., 1986). In experimental BP, both NE and MMP-9 are required for blister formation (Liu et al., 2000a; Liu et al., 1998). MMP-9 is the upstream actor that proteolytically inactivates the physiological inhibitor of NE ( $\alpha 1$-proteinase inhibitor), while NE directly cleaves extracellular matrix proteins, including BP180, resulting in DEJ separation (Liu et al., 2000a; Liu et al., 2000b). These data indicate that NE contributes to the pathogenesis of experimental BP by directly damaging cell-matrix adhesion molecules, which ultimately leads to the detachment of the basal keratinocytes from the basement membrane. However, 
mice lacking NE are unable to sustain recruitment of neutrophils to the skin, suggesting that NE may also contribute to disease progression through its role in recruitment of neutrophils to lesional skin (Liu et al., 2000b). In this study, we investigate the ability of NE to degrade BP180 and examine the functions of the degradation products in vitro and in vivo.

\section{Results}

\subsection{NE degrades recombinant murine $B P 180$ antigen in vitro}

To demonstrate that NE directly degrades the BP180 antigen, we performed in vitro degradation assays by incubating purified $\mathrm{NE}$ with a purified recombinant protein (mBP180ABC) containing NC14A and part of the C13 domain as a substrate (Figure 1). NE cleaved mBP180ABC into 3 distinct fragments, with molecular weights of 15,12 , and $8 \mathrm{kD}$ as determined by SDS-PAGE separation followed by Coomassie blue staining (Figure 1A, Lanes 2-6). No degradation products were observed in the reaction lacking NE (Figure 1A, Lane 7), or in the sample containing NE at time 0 (Figure 1A, Lane 1). The digestion mixtures were also further characterized by immunoblot analysis using an anti-mBP180 antiserum. The anti-mBP180ABC antibodies detected the three bands identified by Coomassie blue staining (Figure 1B, lanes 2-6), and the $12 \mathrm{kD}$ fragment is the predominant band detected after two hours of digestion (Figure 1B, Lane 4). Thus, each of the digestion products contained one or more epitopes recognized by the anti-BP180 antiserum. The time course study also revealed a sequential cleavage of the antigen: the $15 \mathrm{kD}$ and $12 \mathrm{kD}$ fragments appear before the $8 \mathrm{kD}$ fragment. Using mass spectrometry, we identified the location of three NE cleavage sites at amino acid position 506, 561, and 592, respectively in $\mathrm{mBP} 180 \mathrm{ABC}$ (Figure 1C). Cleavage at these three locations produces three peptides, p506, p561, and p592.

Having demonstrated that purified NE degrades mBP180ABC, we next investigated the degradative capability of NE released from neutrophils. Purified neutrophils from WT (NE $+/+$ ) and NE-deficient (NE-/-) mice were degranulated with PMA, and the supernatants were collected and assayed for their ability to degrade mBP180ABC. Digestion with supernatant from $\mathrm{NE}+/+$ neutrophils yielded two fragments, corresponding with the 15 and $12 \mathrm{kD}$ fragments generated by digestion with purified NE (Figure 2, Lanes 2 and 3). A very faint $8 \mathrm{kD}$ band was also seen in the $\mathrm{NE}+/+$ supernatant digestion when sample was overloaded (data not shown). Digestion of mBP180ABC by NE+/+ neutrophil supernatant was completely blocked by addition of the NE inhibitor $\alpha 1$-PI to the reaction mixture (Figure 2, Lane 4), indicating that NE is the proteinase present in the supernatant that is critical for digestion of the BP180 antigen. Supernatant from the NE-/- neutrophils did not digest mBP180ABC (Figure 2, Lane 5), further confirming that NE is the major enzyme that is responsible for BP180 degradation.

\subsection{Neutrophil elastase-cleaved $\mathrm{mBP} 180$ fragments are chemotactic for neutrophils}

We previously showed that mice lacking NE are unable to sustain recruitment of neutrophils to the skin (Liu et al., 2000b). These data indicate that NE may be involved in neutrophil infiltration into lesional skin in experimental BP. We hypothesized that NE digestion of extracellular matrix components generates chemotactic peptides that recruit inflammatory cells to the skin. To investigate this proposed mechanism of NE-mediated neutrophil recruitment, we first tested the three peptides identified in Section 2.1 for neutrophil chemotactic activity using a modified Boyden chamber. Peptides p506 and p592 did not exhibit chemotactic activity above the activity observed in the PBS control (Figure 3A, bars 1, 3-5, 9-11). However, peptide 561 demonstrated strong chemotactic activity at concentrations ranging from $10^{-5} \mathrm{M}$ to $10^{-7} \mathrm{M}$ (Figure $3 \mathrm{~A}$, bars 6-8). 
We next investigated the chemotactic activity of the three peptides in vivo. Neonatal C57BL/6J mice were injected intradermally with PBS, p506, p561, p592, or IL-8, a neutrophil chemoattractant, and neutrophil infiltration was quantified by measuring myeloperoxidase activity (MPO) in the skin. Neutrophil recruitment to the skin in the mice injected with p506 or p592 was equivalent to PBS-injected mice (Figure 3B, bars 1, 3-4, 78). In contrast, mice injected with p561 exhibited a significant increase in the level of neutrophil infiltration to the skin, although not as high a level as the mice injected with IL-8 (Figure 3B, bars 2, 5-6). Taken together, peptide p561 generated by NE degradation of BP180 acts as a neutrophil chemoattractant both in vitro and in vivo.

\subsection{Local injection of NE induces neutrophil infiltration}

If NE directly damages the extracellular matrix and generates a chemotactic factor that recruits neutrophils to the skin, then directly injecting NE into neonatal mice should be sufficient to trigger BP180 degradation and neutrophil infiltration, even in the absence of pathogenic anti-BP180 antibodies and the other inflammatory cells and cytokines known to contribute to the pathogenesis of BP. To test this hypothesis, we injected neonatal B6 mice intradermally with NE and quantified neutrophil infiltration to the skin. As expected, NE injection significantly increased the number of neutrophils present in the skin as evidenced by routine histology examination (Figure 4A, left panel) and by enzymatic activity assay of the neutrophil marker MPO (Figure 4B). Prolonged NE incubation led to histological separation of epidermis from the underlying dermis (Figure 4A, middle panel). The neutrophil recruitment and dermalepidermal separation observed with NE injection is completely blocked by co-injection with $\alpha 1$-PI (Figure 4A, right panel). These results suggest that NE cleaves BP180 and degradation of BP180 results in neutrophil infiltration.

To determine the ability of NE to directly degrade BP180 in mouse skin, we incubated epidermis from neonatal mice with $\mathrm{NE}$ at $37^{\circ} \mathrm{C}$. After 30 minutes of incubation, the full length $180 \mathrm{kDa}$ protein was converted into a lower molecular weight band (Figure 4C, lane 3). Epidermis incubated at $37^{\circ} \mathrm{C}$ for 30 minutes without NE did not exhibit detectable degradation (Figure 4C, lane 2). In addition, $\alpha 1$-PI co-incubation completely abolished BP180 cleavage by NE (Figure 4C, lane 4), further confirming the specificity of NE for BP180 degradation.

\subsection{Neutrophil elastase cleaves the native human BP180 molecule}

BP180 exists as a trimer in the skin. To determine whether NE degrades the native human BP180 trimer molecule, we first detected BP180 degradation in the human skin epidermis incubated with NE by immunoblotting. Similar to the mouse epidermal BP180 degradation (Figure 4C), the full-length human BP180 in the skin was cleaved into a lower molecular weight band when incubated with NE (Figure 5A, lane 2). To directly show that NE degrades human BP180 trimer, protein extracts of the cultured human primary keratinocytes were incubated with $\mathrm{NE}$ at $37^{\circ} \mathrm{C}$ for $30 \mathrm{~min}$, separated by SDS-PAGE gel under native or denaturing/reducing conditions, and then probed by anti-NC16A antibody. As expected, human BP180 trimer and monomer bands were seen under the native and reducing/ denaturing conditions, respectively (Figure 5B, top panel, lanes 1,2). In the presence of NE, a trimer band with lower molecular weight and cleaved monomer bands were identified under the native and reducing/denaturing conditions, respectively (Figure 5B, top panel, lanes 3,4). Small BP180 fragments were also recovered by running samples in $18 \%$ SDS=PAGE gel (Figure 5B. bottom panel, lane 2). These results demonstrate that NE is capable of degrading native BP180 trimer. 


\section{Discussion}

Accumulation of neutrophils in the skin is required for blister formation in experimental BP (Liu et al., 1995; Liu et al., 1998). While the degranulation of mast cells releases chemoattractants that initially recruit neutrophils to the skin, a secondary amplification phase of neutrophil accumulation occurs that is not mediated by mast cells. In this study, we provide evidence that NE, an enzyme secreted by the initial wave of activated neutrophils, cleaves mBP180 within the immunodominant domain NC14A and generates a $12 \mathrm{kD}$ digestion product that is chemotactic for neutrophils. This $12 \mathrm{kD}$ fragment, referred to as $\mathrm{p} 561$, is chemotactic for neutrophils both in vitro and in vivo. We also found that local injection of NE causes dermal-epidermal separation and neutrophil infiltration to the skin in mice. Importantly, NE also cleaves the human native BP180 trimer molecule. Taken together, we conclude that NE digests BP180 into a chemoattractant fragment that recruits neutrophils to the skin in mice. This second wave of neutrophil recruitment amplifies the inflammatory and proteolytic environment required for the extensive extracellular matrix disruption that occurs prior to dermal-epidermal separation and blister formation in experimental BP.

BP180 is not the only basement membrane protein that generates chemotactic fragments following proteolytic cleavage. Fragments derived from a number of collagens, elastins, and laminins are also reported to attract inflammatory cells, such as neutrophils, monocytes, and macrophages (Adair-Kirk and Senior, 2008; Clark et al., 1988; Houghton et al., 2006; Hunninghake et al., 1981; Senior et al., 1980; Weathington et al., 2006). Laminin-332 digestion with NE produces fragments chemotactic for neutrophils, as are fragments generated by laminin-111 digestion with NE or cathspesin G (Gresham et al., 1996; Mydel et al., 2008). In chronic obstructive pulmonary disease, elastin degradation by MMP-12 generates chemotactic fragments that recruit monocytes to the alveolar airspace (Houghton et al., 2006).

Our data strongly suggest that NE is the major protease responsible for BP180 degradation based on following observations: 1) both purified NE and degranulated neutrophil supernatant produce identical degradation products of the recombinant mBP180;2) NE inhibitor $\alpha 1$-PI completely inhibits the recombinant mBP180 degradation by degranulated neutrophil supernatant; and 3) supernatant from degranulated NE-deficient neutrophils fails to cleave BP180. Our present findings are very likely to be relevant to human BP. Our data show that NE directly cleaves human native BP180 trimer. It has been reported that human BP blister fluids contain high levels of NE, and degradation of recombinant human BP180 by BP blister fluid depends on NE activity (Verraes et al., 2001). It remains to be determined whether NE cleaves BP180 at the same or similar site as mBP180, leading to generation of p561-like chemotactic peptides in patients with BP. Besides NE, MMP-9, cathepsin G, collagenase, plasmin, and plasminogen activators have also been detected in BP blister fluid and within lesional/perilesional skin sites on BP patients (Janoff, 1985; Senior and Campbell, 1983; Weiss, 1989;Gissler et al., 1992; Grando et al., 1989a; Grando et al., 1989b; Kramer and Reinartz, 1993; Oikarinen et al., 1983; Stahle-Backdahl et al., 1994; Welgus et al., 1986). MMP-9 is capable of cleaving the recombinant human BP180 NC16A domain (Stahle-Backdahl et al., 1994). Therefore, our data cannot rule out the possibility that some of these proteases are involved, either directly or indirectly through interaction with NE, in BP blistering.

In summary, the data presented here strongly suggest that $\mathrm{NE}$ is important for $\mathrm{BP}$ disease development. NE directly cleaves the hemidesmosomal protein BP180 and generates peptides with neutrophil chemotactic activity to amplify the inflammatory cascade in mice. Our data present a new possible target for treatment in human BP. 


\section{Experimental procedures}

\subsection{Reagents}

Human neutrophil elastase, $\alpha 1$-proteinase inhibitor ( $\alpha 1-\mathrm{PI})$, and myeloperoxidase (MPO) were from Athens Research and Technology, Inc. (Athens, Georgia). Phorbol myristate acetate (PMA) was obtained from Sigma Co. (St. Louis, MO). Methoxysuccinyl-Ala-AlaPro-Val-p-nitroanalide (Met-OSuc-Ala-Ala-Pro-Val-pNA, or AAPV) was from Enzyme Systems Products (Dublin, CA). Protein concentration was determined with the RC DC protein assay purchased from Bio-Rad Laboratories (Hercules, CA). The ECL Western blotting analysis kit was purchased from GE Healthcare (Piscataway, NJ).

\subsection{Laboratory animals}

Breeding pairs of C57BL/6J mice were purchased from Jackson Laboratories (Bar Harbor, $\mathrm{ME})$. NE null mutants (NE-/-) and the matched control littermates (NE+/+) were generated as described previously (Belaaouaj et al., 1998). These animals were maintained at the University of North Carolina at Chapel Hill Animal Resource Center. Neonatal mice (24-36 $\mathrm{h}$ old with body weights between 1.4 and $1.6 \mathrm{~g}$ ) were used for in vivo experiments. All animal care and animal experiments were approved by the UNC Animal Care Committee and were in accordance with the National Institutes of Health guidelines.

\subsection{Preparation of pathogenic anti-BP180 IgG}

The preparation of recombinant murine BP180 and the immunization of rabbits were performed as previously described (Liu et al., 1993). Briefly, a segment of the ectodomain of the murine BP180 antigen (Li et al., 1993) was expressed as a glutathione S-transferase (GST) fusion protein using the pGEX prokaryotic expression system (Pharmacia LKB Biotechnology, Piscataway, NJ). The murine BP180 fusion protein, designated GSTmBP180ABC containing NC14A and half of C13 domains (Figure 1C), was purified to homogeneity by affinity chromatography using a glutathione-Agarose column (Liu et al., 1992). New Zealand White rabbits were immunized with the purified mBP180 fusion protein and the $\operatorname{IgG}$ fraction from the serum (designated R621) was purified as previously described (Liu et al., 1993). The IgG fractions were concentrated, sterilized by ultrafiltration and the protein concentrations determined by $\mathrm{OD}_{280}[\mathrm{E}(1 \%, 1 \mathrm{~cm})=13.6]$. The titers of anti-murine BP180 antibodies in both the unfractionated rabbit serum and in the purified $\operatorname{IgG}$ fraction were assayed by indirect immunofluorescence (IF) using mouse skin cryosections as substrate. The antibody preparations were also tested by immunoblotting against the GST-mBP180ABC fusion protein. The IF and immunoblotting techniques have been reported elsewhere (Liu et al., 1993).

\subsection{Neutrophil elastase digestion and analysis of $\mathrm{mBP} 180$ peptides}

The GST portion of the GST-mBP180ABC fusion protein was removed by PreScission protease cleavage, followed by glutathione column. Purified mBP180ABC protein $(4 \mu \mathrm{g})$ was incubated with highly purified human $\mathrm{NE}(0.02 \mu \mathrm{g})$ in the in vitro degradation buffer containing $50 \mathrm{mM}$ Tris-Cl, $\mathrm{pH} 7.5$, and $1 \mathrm{mM}$ DTT. Reactions were carried out at $37^{\circ} \mathrm{C}$ for 0 -2 hours and terminated by adding an equal volume of SDS-PAGE sample buffer and heating at $100^{\circ} \mathrm{C}$ for 5 minutes. Reaction mixtures were then resolved by electrophoresis through $21 \%$ SDS-PAGE gels. The mBP180ABC and its degraded fragments were detected using Coomassie blue staining and immunoblotting using rabbit anti-mBP180 IgG. The NEgenerated peptides of mBP180ABC were analyzed by MS- mass spectrometry (UNC-Duke Proteomics Center, University of North Carolina at Chapel Hill). 


\subsection{Neutrophil isolation, in vitro neutrophil degranulation, and digestion of mBP180ABC by degranulated neutrophil supernatants}

Neutrophils were isolated from heparinized blood of wild-type and NE-deficient mice by dextran sedimentation followed by separation on a density gradient as described (Metcalf, 1985). In vitro neutrophil degranulation was performed as described (Desrochers et al., 1992). Purified neutrophils from NE+/+ and NE-/- mice were suspended in Hank's balanced salt solution (GIBCO) at a final concentration of $10^{7}$ cells $/ \mathrm{ml}$ and triggered with 50 $\mathrm{ng} / \mathrm{ml}$ phorbol myristate acetate for $15 \mathrm{~min}$ at $37^{\circ} \mathrm{C}$. The neutrophil supernatants were collected by centrifugation at $1,000 \mathrm{~g}$ for $5 \mathrm{~min}$ at $4^{\circ} \mathrm{C}$. The supernatants $(5 \mu \mathrm{l})$ were incubated with purified $\mathrm{mBP} 180 \mathrm{ABC}(4 \mu \mathrm{g})$ at $37^{\circ} \mathrm{C}$ for $30 \mathrm{~min}$ in the absence or presence of the NE inhibitor, $\alpha 1$-PI. Reaction mixtures were resolved by $21 \%$ SDS-PAGE gels, and the mBP180ABC and its degraded fragments were detected by immunoblotting using rabbit anti-mBP180 IgG.

\subsection{Neutrophil chemotaxis assays}

PMN chemotaxis was quantified using a modification of the Boyden chamber technique (Betsuyaku et al., 1999). A cell suspension containing $3.0 \times 10^{6} \mathrm{PMN} / \mathrm{ml}$ (the total cell number loaded per well was adjusted to give equal numbers of PMNs) in HBSS with $1 \mathrm{mM}$ $\mathrm{CaCl}_{2}, 1 \mathrm{mM} \mathrm{MgCl} \mathrm{Mg}_{2}$ containing $0.1 \% \mathrm{BSA}$, was placed in the top wells of a 48-well microchemotaxis chamber (Neuro Probe Inc., Bethesda, Maryland, USA). A polyvinylpyrolidone (PVP)-free polycarbonate filter (3- $\mu \mathrm{m}$ pore size; Poretics Products, Livermore, California, USA) separated the cells from lower wells containing the indicated chemoattractant. The chamber was incubated for $90 \mathrm{~min}$ at $37^{\circ} \mathrm{C}$ in a $5 \% \mathrm{CO}_{2}$ humidified atmosphere. After incubation, the filter was stained with LeukoStat (Fisher Scientific Co., Pittsburgh, Pennsylvania, USA), and the number of PMNs on the undersurface of the filter was counted in five random high-power fields $(\times 400)$ for each of triplicate filters.

For in vivo chemotaxis assay, neonatal C57BL/6J mice (1-2 days old) were injected intradermally with $50 \mu \mathrm{l}$ of PBS, NE-digested mBP180 peptides $\left(10^{-5}-10^{-6} \mathrm{M}\right.$ in PBS), or IL-8 $\left(10^{-7} \mathrm{M}\right)$. Four h later, skin sections at the injection sites were obtained, and infiltrating neutrophils were quantified by measuring MPO enzyme activity in the skin protein extracts as described below.

\subsection{Quantification of PMN accumulation in the mouse skin}

Tissue myeloperoxidase (MPO) activity was used as an indicator of PMNs within skin samples of experimental animals, as described elsewhere (Bradley et al., 1982). A standard reference curve was first established by obtaining activity levels on aliquots of known amounts of purified MPO. The mouse skin samples were extracted by homogenization in a buffer containing $0.1 \mathrm{M}$ Tris-Cl, $\mathrm{pH} 7.6,0.15 \mathrm{M} \mathrm{NaCl}, 0.5 \%$ hexadecyltrimethylammonium bromide. MPO activity levels in supernatant fractions were determined by the change in optical density at $460 \mathrm{~nm}$ resulting from decomposition of $\mathrm{H}_{2} \mathrm{O}_{2}$ in the presence of $o$ dianisidine. MPO content was expressed as relative MPO activity $\left(\mathrm{OD}_{460 \mathrm{~nm}} / \mathrm{mg}\right.$ protein). Protein concentrations were determined by the Bio-RAD dye binding assay using BSA as a standard.

\subsection{Digestion of epidermis and native BP180 trimer by neutrophil elastase}

Fresh neonatal mouse skin or human foreskin was incubated in MEM medium containing 10 $\mathrm{mM}$ dithiothreitol (dTT) for 60 minutes at room temperature to separate the epidermis from the dermis. The epidermis was washed three times with PBS, and then $10 \mathrm{mg}$ of epidermis was incubated in $100 \mu \mathrm{lBS}$ with or without $0.5 \mu \mathrm{g}$ NE for 30 minutes at $37^{\circ} \mathrm{C}$. The epidermis was washed four times with PBS and the epidermal proteins were extracted by 
mechanical homogenization for two minutes on ice in buffer containing $65 \mathrm{mM}$ Tris- $\mathrm{HCl}$, 20mM EDTA, 2mM PMSF, 2\% SDS, $0.5 \%$ NP-40, pH 6.8 plus proteinase inhibitors. Protein extracts were analyzed for BP180 degradation by immunoblot.

To detect degradation of native human BP180 trimer by NE, human BP180/type XVII was extracted from normal human keratinocytes as described previously(Schumann et al., 2000). Normal human keratinocyte extract $(50 \mu \mathrm{l})$ was incubated with highly purified human NE $(0.05 \mu \mathrm{g})$ at $37^{\circ} \mathrm{C}$ for 30 minutes. Reaction mixtures were then resolved by electrophoresis through $6 \%$ and $18 \%$ SDS-PAGE gels. The human collagen XVII and its degraded fragments were detected by immunoblotting using anti-mBP180 IgG.

\subsection{Statistical analysis}

The data were expressed as mean \pm SEM and were analyzed using Student's $t$-test. A $p$ value less than 0.05 was considered significant.

\section{Acknowledgments}

We thank Dr. Pamela Groben Ms. Joy Miller for routine histology. This work was supported in part by U.S. Public Health Service NIH grants AI40768 and AI61430 (Z. L.), AR052109 and AR053313 (N.L.), AI49427 (D.S.R.), AR32599 and AR32081 (L.A.D.), R01 HL082541 (S.D.S.), NHLBI/NIH P01 HL29594 and the Alan A. and Edith L. Wolf Charitable Trust/Barnes-Jewish Hospital Foundation (R.S.). L.L. was supported in part by a pre-doctoral fellowship from China Scholarship Council. L.H. was supported in part by a pre-doctoral fellowship from NIH AI007273.

\section{References}

Adair-Kirk TL, Senior RM. Fragments of extracellular matrix as mediators of inflammation. Int J Biochem Cell Biol. 2008; 40:1101-1110. [PubMed: 18243041]

Bedane C, McMillan JR, Balding SD, Bernard P, Prost C, Bonnetblanc JM, Diaz LA, Eady RA, Giudice GJ. Bullous pemphigoid and cicatricial pemphigoid autoantibodies react with ultrastructurally separable epitopes on the BP180 ectodomain: evidence that BP180 spans the lamina lucida. J Invest Dermatol. 1997; 108:901-901. [PubMed: 9182819]

Belaaouaj A, McCarthy R, Baumann M, Gao Z, Ley TJ, Abraham SN, Shapiro SD. Mice lacking neutrophil elastase reveal impaired host defense against gram negative bacterial sepsis. Nat Med. 1998; 4:615-618. [PubMed: 9585238]

Betsuyaku T, Liu F, Senior RM, Haug JS, Brown EJ, Jones SL, Matsushima K, Link DC. A functional granulocyte colony-stimulating factor receptor is required for normal chemoattractant-induced neutrophil activation. J Clin Invest. 1999; 103:825-832. [PubMed: 10079103]

Bradley PP, Priebat DA, Christensen RD, Rothstein G. Measurement of cutaneous inflammation: estimation of neutrophil content with an enzyme marker. J Invest Dermatol. 1982; 78:206-209. [PubMed: 6276474]

Chen R, Ning G, Zhao ML, Fleming MG, Diaz LA, Werb Z, Liu Z. Mast cells play a key role in neutrophil recruitment in experimental bullous pemphigoid. J Clin Invest. 2001; 108:1151-1158. [PubMed: 11602622]

Clark RA, Wikner NE, Doherty DE, Norris DA. Cryptic chemotactic activity of fibronectin for human monocytes resides in the 120-kDa fibroblastic cell-binding fragment. J Biol Chem. 1988; 263:12115-12123. [PubMed: 3403561]

Desrochers PE, Mookhtiar K, Van Wart HE, Hasty KA, Weiss SJ. Proteolytic inactivation of alpha 1proteinase inhibitor and alpha 1-antichymotrypsin by oxidatively activated human neutrophil metalloproteinases. J Biol Chem. 1992; 267:5005-5012. [PubMed: 1311327]

Diaz LA, Ratrie H, Saunders WS 3rd, Futamura S, Squiquera HL, Anhalt GJ, Giudice GJ. Isolation of a human epidermal cDNA corresponding to the $180-\mathrm{kD}$ autoantigen recognized by bullous pemphigoid and herpes gestationis sera. Immunolocalization of this protein to the hemidesmosome. J Clin Invest. 1990; 86:1088-1094. [PubMed: 1698819] 
Gissler HM, Simon MM, Kramer MD. Enhanced association of plasminogen/plasmin with lesional epidermis of bullous pemphigoid. Br J Dermatol. 1992; 127:272-277. [PubMed: 1390172]

Giudice GJ, Emery DJ, Diaz LA. Cloning and primary structural analysis of the bullous pemphigoid autoantigen BP180. J Invest Dermatol. 1992; 99:243-250. [PubMed: 1324962]

Giudice GJ, Emery DJ, Zelickson BD, Anhalt GJ, Liu Z, Diaz LA. Bullous pemphigoid and herpes gestationis autoantibodies recognize a common non-collagenous site on the BP180 ectodomain. $\mathrm{J}$ Immunol. 1993; 151:5742-5750. [PubMed: 8228259]

Grando SA, Glukhenky BT, Drannik GN, Epshtein EV, Kostromin AP, Korostash TA. Mediators of inflammation in blister fluids from patients with pemphigus vulgaris and bullous pemphigoid. Arch Dermatol. 1989a; 125:925-930. [PubMed: 2662908]

Grando SA, Glukhenky BT, Drannik GN, Kostromin AP, Chernyavsky AI. Cytotoxic proteases in blister fluid of pemphigus and pemphigoid patients. Int J Tissue React. 1989b; 11:195-201. [PubMed: 2699467]

Gresham HD, Graham IL, Griffin GL, Hsieh JC, Dong LJ, Chung AE, Senior RM. Domain-specific interactions between entactin and neutrophil integrins. G2 domain ligation of integrin alpha3beta1 and $\mathrm{E}$ domain ligation of the leukocyte response integrin signal for different responses. J Biol Chem. 1996; 271:30587-30594. [PubMed: 8940031]

Hirako Y, Usukura J, Nishizawa Y, Owaribe K. Demonstration of the molecular shape of BP180, a 180-kDa bullous pemphigoid antigen and its potential for trimer formation. J Biol Chem. 1996; 271:13739-13745. [PubMed: 8662839]

Hopkinson SB, Riddelle KS, Jones JC. Cytoplasmic domain of the 180-kD bullous pemphigoid antigen, a hemidesmosomal component: molecular and cell biologic characterization. J Invest Dermatol. 1992; 99:264-270. [PubMed: 1512461]

Houghton AM, Quintero PA, Perkins DL, Kobayashi DK, Kelley DG, Marconcini LA, Mecham RP, Senior RM, Shapiro SD. Elastin fragments drive disease progression in a murine model of emphysema. J Clin Invest. 2006; 116:753-759. [PubMed: 16470245]

Hunninghake GW, Davidson JM, Rennard S, Szapiel S, Gadek JE, Crystal RG. Elastin fragments attract macrophage precursors to diseased sites in pulmonary emphysema. Science. 1981; 212:925-927. [PubMed: 7233186]

Ishiko A, Shimizu H, Kikuchi A, Ebihara T, Hashimoto T, Nishikawa T. Human autoantibodies against the 230-kD bullous pemphigoid antigen (BPAG1) bind only to the intracellular domain of the hemidesmosome, whereas those against the $180-\mathrm{kD}$ bullous pemphigoid antigen (BPAG2) bind along the plasma membrane of the hemidesmosome in normal human and swine skin. J Clin Invest. 1993; 91:1608-1615. [PubMed: 7682575]

Janoff A. Elastase in tissue injury. Annu Rev Med. 1985; 36:207-216. [PubMed: 3888051]

Jordon RE, Beutner EH, Witebsky E, Blumental G, Hale WL, Lever WF. Basement zone antibodies in bullous pemphigoid. JAMA. 1967; 200:751-756. [PubMed: 4164640]

Kramer MD, Reinartz J. The autoimmune blistering skin disease bullous pemphigoid. The presence of plasmin/alpha 2-antiplasmin complexes in skin blister fluid indicates plasmin generation in lesional skin. J Clin Invest. 1993; 92:978-983. [PubMed: 7688770]

Labib RS, Anhalt GJ, Patel HP, Mutasim DF, Diaz LA. Molecular heterogeneity of the bullous pemphigoid antigens as detected by immunoblotting. J Immunol. 1986; 136:1231-1235. [PubMed: 2418109]

Lever WF. Pemphigus. Medicine (Baltimore). 1953; 32:1-123. [PubMed: 13024494]

Li K, Tamai K, Tan EM, Uitto J. Cloning of type XVII collagen. Complementary and genomic DNA sequences of mouse 180-kilodalton bullous pemphigoid antigen (BPAG2) predict an interrupted collagenous domain, a transmembrane segment, and unusual features in the 5'-end of the gene and the 3'-untranslated region of the mRNA. J Biol Chem. 1993; 268:8825-8834. [PubMed: 8473327]

Liu Z, Diaz LA, Haas AL, Giudice GJ. cDNA cloning of a novel human ubiquitin carrier protein. An antigenic domain specifically recognized by endemic pemphigus foliaceus autoantibodies is encoded in a secondary reading frame of this human epidermal transcript. J Biol Chem. 1992; 267:15829-15835. [PubMed: 1379239] 
Liu Z, Diaz LA, Troy JL, Taylor AF, Emery DJ, Fairley JA, Giudice GJ. A passive transfer model of the organ-specific autoimmune disease, bullous pemphigoid, using antibodies generated against the hemidesmosomal antigen, BP180. J Clin Invest. 1993; 92:2480-2488. [PubMed: 7693763]

Liu Z, Giudice GJ, Swartz SJ, Fairley JA, Till GO, Troy JL, Diaz LA. The role of complement in experimental bullous pemphigoid. J Clin Invest. 1995; 95:1539-1544. [PubMed: 7706459]

Liu Z, Giudice GJ, Zhou X, Swartz SJ, Troy JL, Fairley JA, Till GO, Diaz LA. A major role for neutrophils in experimental bullous pemphigoid. J Clin Invest. 1997; 100:1256-1263. [PubMed: 9276744]

Liu Z, Shapiro SD, Zhou X, Twining SS, Senior RM, Giudice GJ, Fairley JA, Diaz LA. A critical role for neutrophil elastase in experimental bullous pemphigoid. J Clin Invest. 2000a; 105:113-123. [PubMed: 10619867]

Liu Z, Shipley JM, Vu TH, Zhou X, Diaz LA, Werb Z, Senior RM. Gelatinase B-deficient mice are resistant to experimental bullous pemphigoid. J Exp Med. 1998; 188:475-482. [PubMed: 9687525]

Liu Z, Zhou X, Shapiro SD, Shipley JM, Twining SS, Diaz LA, Senior RM, Werb Z. The serpin alpha1-proteinase inhibitor is a critical substrate for gelatinase B/MMP-9 in vivo. Cell. 2000b; 102:647-655. [PubMed: 11007483]

Metcalf, JA.; Gallin, JI.; Nauseef, WM.; Root, abd R.K. Laboratory Manual of Neutrophil Function. Raven Press; New York: 1985. p. 2-10.

Mutasim DF, Takahashi Y, Labib RS, Anhalt GJ, Patel HP, Diaz LA. A pool of bullous pemphigoid antigen(s) is intracellular and associated with the basal cell cytoskeletonhemidesmosome complex. J Invest Dermatol. 1985; 84:47. [PubMed: 3880796]

Mydel P, Shipley JM, Adair-Kirk TL, Kelley DG, Broekelmann TJ, Mecham RP, Senior RM. Neutrophil elastase cleaves laminin-332 (laminin-5) generating peptides that are chemotactic for neutrophils. J Biol Chem. 2008; 283:9513-9522. [PubMed: 18178964]

Nishizawa Y, Uematsu J, Owaribe K. HD4, a $180 \mathrm{kDa}$ bullous pemphigoid antigen, is a major transmembrane glycoprotein of the hemidesmosome. J Biochem. 1993; 113:493-501. [PubMed: 8514739]

Oikarinen AI, Zone JJ, Ahmed AR, Kiistala U, Uitto J. Demonstration of collagenase and elastase activities in the blister fluids from bullous skin diseases. Comparison between dermatitis herpetiformis and bullous pemphigoid. J Invest Dermatol. 1983; 81:261-266. [PubMed: 6309988]

Schumann H, Baetge J, Tasanen K, Wojnarowska F, Schacke H, Zillikens D, Bruckner-Tuderman L. The shed ectodomain of collagen XVII/BP180 is targeted by autoantibodies in different blistering skin diseases. Am J Pathol. 2000; 156:685-695. [PubMed: 10666397]

Senior RM, Campbell EJ. Neutral proteinases from human inflammatory cells. A critical review of their role in extracellular matrix degradation. Clin Lab Med. 1983; 3:645-666. [PubMed: 6360502]

Senior RM, Griffin GL, Mecham RP. Chemotactic activity of elastin-derived peptides. J Clin Invest. 1980; 66:859-862. [PubMed: 6903189]

Stahle-Backdahl M, Inoue M, Guidice GJ, Parks WC. $92-\mathrm{kD}$ gelatinase is produced by eosinophils at the site of blister formation in bullous pemphigoid and cleaves the extracellular domain of recombinant 180-kD bullous pemphigoid autoantigen. J Clin Invest. 1994; 93:2022-2030. [PubMed: 8182134]

Stanley, JR. Bullous Pemphigoid. In: Freedberg, I.; Eisen, AZ.; Wolff, K.; Austen, KF.; Goldsmith, LA.; Katz, SI., editors. Fitzpatrick's Dermatology in General Medicine. McGraw-Hill; New York: 1999. p. 666-671.

Stanley JR, Hawley-Nelson P, Yuspa SH, Shevach EM, Katz SI. Characterization of bullous pemphigoid antigen: a unique basement membrane protein of stratified squamous epithelia. Cell. 1981; 24:897-903. [PubMed: 7018697]

Van den Bergh F, Fu CL, Olague-Marchan M, Giudice GJ. The NC16A domain of collagen XVII plays a role in triple helix assembly and stability. Biochem Biophys Res Commun. 2006; 350:1032-1037. [PubMed: 17045967] 
Verraes S, Hornebeck W, Polette M, Borradori L, Bernard P. Respective contribution of neutrophil elastase and matrix metalloproteinase 9 in the degradation of BP180 (type XVII collagen) in human bullous pemphigoid. J Invest Dermatol. 2001; 117:1091-1096. [PubMed: 11710917]

Weathington NM, van Houwelingen AH, Noerager BD, Jackson PL, Kraneveld AD, Galin FS, Folkerts G, Nijkamp FP, Blalock JE. A novel peptide CXCR ligand derived from extracellular matrix degradation during airway inflammation. Nat Med. 2006; 12:317-323. [PubMed: 16474398]

Weiss SJ. Tissue destruction by neutrophils. N Engl J Med. 1989; 320:365-376. [PubMed: 2536474]

Welgus HG, Bauer EA, Stricklin GP. Elevated levels of human collagenase inhibitor in blister fluids of diverse etiology. J Invest Dermatol. 1986; 87:592-596. [PubMed: 3021860]

Zillikens D, Rose PA, Balding SD, Liu Z, Olague-Marchan M, Diaz LA, Giudice GJ. Tight clustering of extracellular BP180 epitopes recognized by bullous pemphigoid autoantibodies. J Invest Dermatol. 1997; 109:573-579. [PubMed: 9326393] 


\section{Highlights}

$>\quad$ Neutrophil elastase (NE) is required for experimental bullous pemphigoid.

$>\quad$ NE directly cleaves BP180 in mouse and human skin.

$>\quad$ Recombinant murine BP180 is degraded into small peptides by NE.

$>\quad$ One small peptide is chemotactic for neutrophils in mice both in vitro and in vivo.

$>\quad$ Local injection of neutrophil elastase recruits neutrophils to the skin in mice. 
A. CB staining

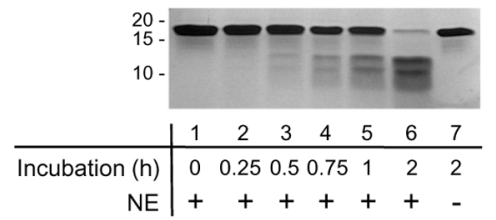

B. Immunoblotting

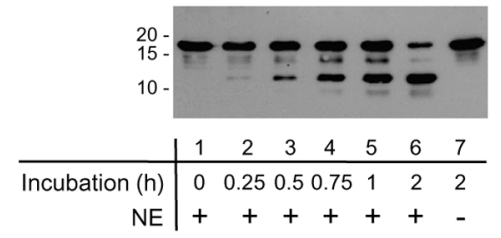

C. Cleavage sites

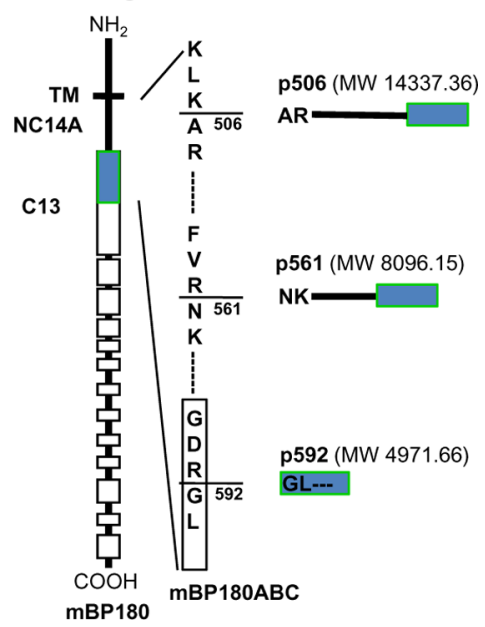

Figure 1. Neutrophil elastase cleaves BP180

mBP180ABC containing NC14A and N-terminal half of C13 domains (see panel C) $(4 \mu \mathrm{g})$ was incubated with neutrophil elastase (NE, $0.02 \mu \mathrm{g}$ ) at $37^{\circ} \mathrm{C}$ for $0-2 \mathrm{~h}$. Degradation products of $\mathrm{mBP} 180 \mathrm{ABC}$ were then resolved by $21 \%$ SDS-PAGE, visualized by Coomassie blue (CB) staining and immunoblotting, and analyzed by mass spectrometry. (A) CB staining. Fragments of approximately $15 \mathrm{kD}, 12 \mathrm{kD}$, and $8 \mathrm{kD}$ were generated from the cleavage of $\mathrm{mBP} 180 \mathrm{ABC}$ by NE (lanes 2-6). No degradation products were seen after incubation for $2 \mathrm{~h}$ without NE (lane 7). (B) Immunoblotting. Anti-mBP180ABC IgG identified three fragments with molecular weights of approximately $15 \mathrm{kD}, 12 \mathrm{kD}$, and $8 \mathrm{kD}$ (lanes 2-6). (C) NE cleavage sites. The location of mBP180ABC and the NE cleavage sites within the mBP180ABC are depicted. The schematic diagram at the left is a structural representation of mouse BP180. The horizontal black bar designates the transmembrane domain (TM). The COOH-terminal extracellular region is made up of 13 collagen triplehelical (open bar) and 14 noncollagenous (closed bar) domains. NC14A represents the $14^{\text {th }}$ noncollagenous domain and $\mathrm{C} 13$ the $13^{\text {th }}$ collagenous domain. The purified recombinant $\mathrm{mBP} 180 \mathrm{ABC}$ protein is a 145 amino acid fragment of the mBP180 extracellular domain, made up of an 8-kD NC14A (closed bar) and an 8-kD half of C13 (open bar). The degradation products were excised from Coomassie-stained PVDF membranes and subjected to sequencing analysis. NE cleaved mBP180ABC at 3 sites (amino acid positions 506, 561, and 592). 


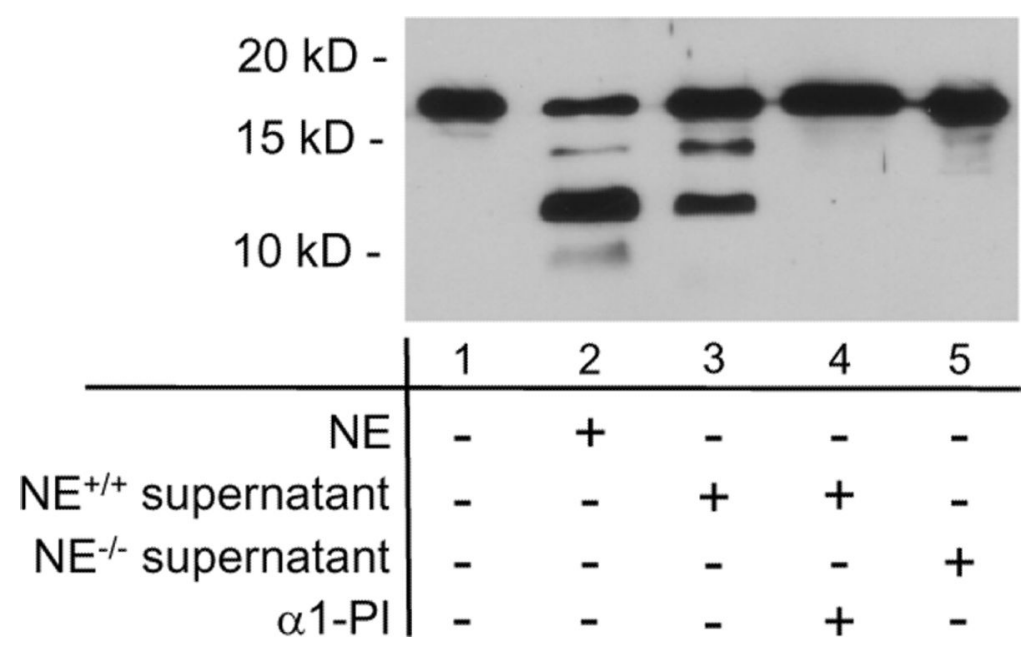

Figure 2. Neutrophil elastase is the major neutrophil proteinase for BP180 degradation $\mathrm{mBP} 180 \mathrm{ABC}(4 \mu \mathrm{g})$ was incubated with buffer control (lane 1), $0.02 \mu \mathrm{g}$ of NE (lane 2), degranulated neutrophil supernatant $(5 \mu \mathrm{l})$ from wild-type mice $\left(\mathrm{NE}^{+/+}\right.$, lane 3$), \mathrm{NE}^{+/+}$in the presence of $\alpha 1$-PI (lane 4), or NE-deficient mice $\left(\mathrm{NE}^{-/-}\right.$, lane 5 ) at $37^{\circ} \mathrm{C}$ for $30 \mathrm{~min}$. Degradation products of mBP180ABC were separated on $21 \%$ SDS-PAGE and analyzed by immunoblotting using antibodies directed against the mBP180ABC. Degranulated neutrophil supernatants from $\mathrm{NE}^{+/+}$and not $\mathrm{NE}^{-/-}$mice cleaved mBP180ABC and its proteolytic activity was completely abolished by addition of the NE inhibitor $\alpha 1-\mathrm{PI}$. 


\section{A. In vitro}

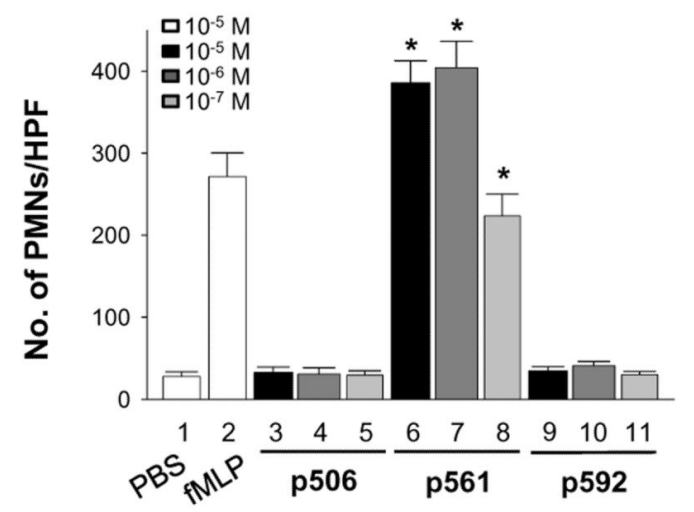

B. In vivo

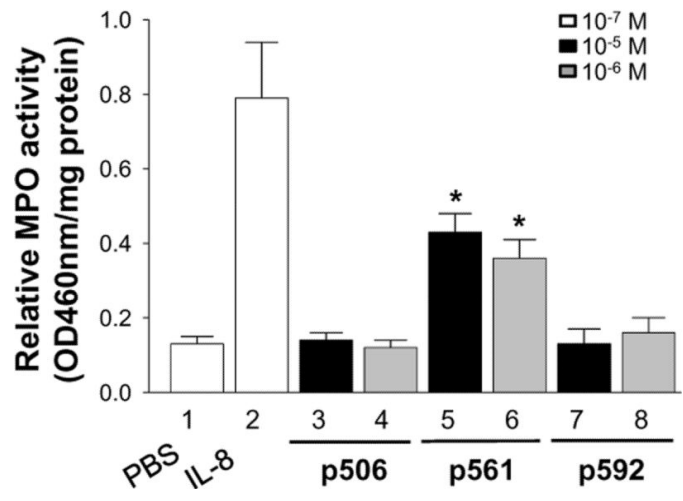

Figure 3. Neutrophil elastase-cleaved BP180 fragments are chemotactic for neutrophils in vitro and in vivo

(A) Chemotaxis assays were performed using mouse neutrophils placed in the upper compartment of a modified Boyden chamber. Buffer control, peptides p506, p561, and p592 $\left(10^{-5}-10^{-7} \mathrm{M}\right)$, or fMLP $\left(10^{-5} \mathrm{M}\right)$ were placed in the lower compartment as the chemoattractant. The average number of migrated neutrophils per high powered field in triplicate wells from three separate experiments was determined. The peptide p561, but not p506 and p592, exhibits chemotactic activity for neutrophils in a dose-dependent fashion (bars 6-8). ${ }^{*} p<0.05$ (p561 vs. buffer control), Student t-test. (B) Neonatal C57BL/6J mice (1-2 days old) were administrated intradermally with PBS, peptides p506, p561, and p592 $\left(10^{-5}-10^{-6} \mathrm{M}\right.$ in $\left.50 \mu \mathrm{lPB}\right)$, or IL-8 $\left(10^{-7} \mathrm{M}\right)$. Four h later, skin sections at the injection sites were obtained, and infiltrating neutrophils were quantified by measuring MPO enzyme activity in the skin protein extracts. Significantly increased levels of infiltrating neutrophils are present in the p561-injected mouse skin (bars 5,6) as compared to the p506- (bars 3,4) and p592-injected (bars 7,8) mouse skin. Levels of neutrophil infiltration were expressed as relative MPO activity (mean $\mathrm{OD}_{460 \mathrm{~nm}}$ reading $+\mathrm{SEM} / \mathrm{mg}$ protein). $\mathrm{n}=3$ for each group, ${ }^{*} p<0.05$ (p561 vs. buffer control), Student t-test. 


\section{A. Skin sections of NE-injected mice}

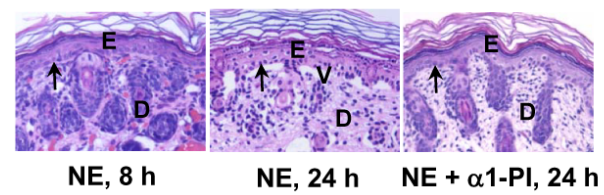

B. NE-induced PMN infiltration in vivo

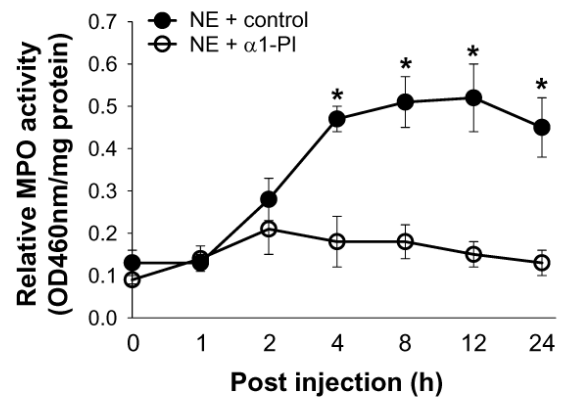

C. Epidermal mBP180 cleavage by NE

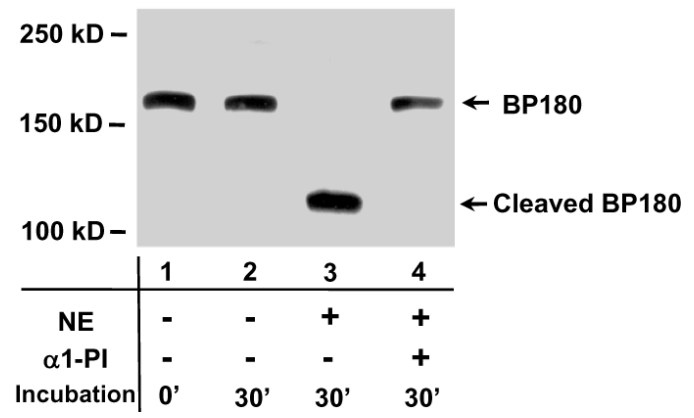

Figure 4. Local injection of NE induces neutrophil infiltration in mice

Neonatal mice were injected intradermally with $100 \mu \mathrm{l}$ of NE $(100 \mu \mathrm{g} / \mathrm{ml}$ in PBS $)$ in the absence and presence of the NE inhibitor $\alpha 1$-proteinase inhibitor $(\alpha 1-\mathrm{PI})$ and the skin sections were examined at different time points. (A) H/E staining. The skin sections were examined by routine $\mathrm{H} / \mathrm{E}$ staining. The skin sections treated with NE showed neutrophil infiltration at 8 and $24 \mathrm{~h}$ and dermal-epidermal separation at $24 \mathrm{~h}$ post injection. X100 magnification. E, epidermis. D, dermis. V, vesicle. Arrow, basal keratinocyte. (B) MPO assay. Neutrophil infiltration in the NE injection sites were quantified by MPO assay at different time points post NE injection and expressed as relative MPO activity (mean $\mathrm{OD}_{460 \mathrm{~nm}}$ reading $+\mathrm{SEM} / \mathrm{mg}$ protein). Significantly increased levels of infiltrating neutrophils in NE-injected mouse skin were seen at 4, 8, 12 and $24 \mathrm{~h}$ as compared to those injected with NE plus $\alpha 1$-PI. ${ }^{*} p<0.05$. $\mathrm{n}=3$. (C) Mouse epidermis was incubated at $37^{\circ} \mathrm{C}$ in PBS alone for 0 (lane 1) or 30 minutes (lane 2), in the presence of NE (lane 3) or NE plus $\alpha 1-P I$ (lane 4), for 30 minutes. Protein extracts were separated by SDS-PAGE and analyzed by immunoblotting with a rabbit anti-mouse BP180 antibody. Significant degradation of BP180 was observed only in the reaction containing NE. Addition of $\alpha 1-P I$ completely abolished degradation of BP180. 


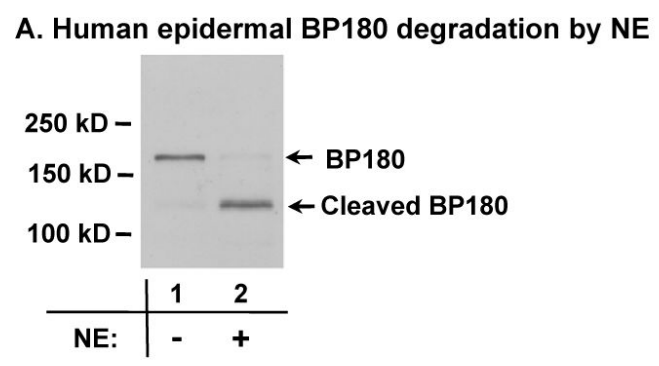

\section{B. Human BP180 trimer degradation by NE \\ $6 \%$ SDS-PAGE:}

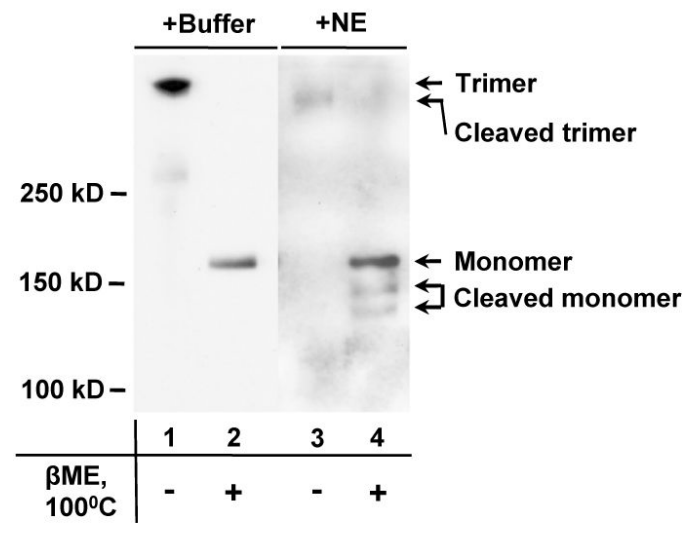

$18 \%$ SDS-PAGE:

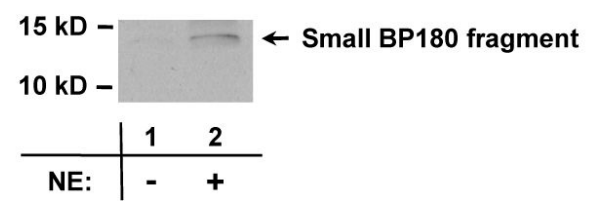

Figure 5. NE cleaves native human BP180

(A). Human foreskin epidermis was incubated at $37^{\circ} \mathrm{C}$ in PBS without (lane 1) or with NE (lane 2) for 30 minutes. Protein extracts were separated by SDS-PAGE and analyzed by immunoblotting with a rabbit anti-BP180NC16A antibody. (B) Protein extracts of cultured human primary keratinocytes were incubated in the presence (lanes 3, 4) or absence (lanes 1, 2) of $\mathrm{NE}$ at $37^{\circ} \mathrm{C}$ for $30 \mathrm{~min}$. The digestion mixtures were separated in $6 \%$ and $18 \% \mathrm{SDS}$ under native (lanes 1,2 ) or denaturing/reducing conditions (lanes 3,4), and then probed with rabbit anti-BP180NC16A antibody. Under native conditions, the full-length BP180 trimer (top panel, lane 1) was degraded into a lower molecular weight trimer band (top panel, lane 3). A band corresponding to a small BP180 fragment was identified on the $18 \%$ SDS-PAGE gel. 